\title{
ニッケル添加湿式分解及び炭素炉原子吸光法による 食品中総七素の簡易定量法
}

\author{
平山晃久，阪上嘉彦，野原基司，福井昭三*® \\ (1980 年 9 月 25 日受理)
}

\begin{abstract}
炭素炉原子吸光法を用いた総ヒ素定量において前処理法として従来の酸分解法を用いるとアルキルヒ 素の損失が多い，そこで，酸分解におけるニッケル添加勃果を利用する簡易な湿式分解法について検討 した. その結果, ニッケルイオンは各種ヒ素化合物のピーク高の増感作用を有し，更にアルキルヒ素に ついても無機ヒ素と同じ感度を与えた. 食品試料 $(1 \sim 5) \mathrm{g}$ ではニッケルイオン $500 \mathrm{mg}$ 必要であった が，この濃度では共存イオンの妨害も余り認められず，カコジル酸の添加実験でも99\%以上の回収率 が得られ，ホットプレート上 $190^{\circ} \mathrm{C}$ で処理するため，多数試料を一度に分解することができる利点も ある・
\end{abstract}

\section{1 緒 言}

現在，食品中の総七素を定量する場合，硫酸一硝酸ある いは硫酸-硝酸一過塩素酸を用いて湿式分解した後定量す る方法1)が一般的である.

著者らはメチルアルソン酸（MMAA）やカコジル酸 (DMAA) の形の七素を定量する際に, 上記の湿式分解 法を用いると分解中に揮散して著しく低い値を与えるこ とや，同一試料についても分解の都度定量値が变動する ことを経験し，生体試料や食品中の総七素を定量する際 の前処理法に改良の余地があると考えていた.

小田中ら ${ }^{2)}$ は, 環境試料中の無機及びアルキルヒ素を 溶媒抽出した後, 炭素炉原子吸光法 (GFAA) により定 量する方法を検討し，GFAA の灰化段階でニッケルイオ ンを添加すると，七素のピークの増感が認められたこと を報告している.

又, Ediger ${ }^{3)}$ は通常の湿式分解法で試料を分解した 後, 同様に GFAA の灰化段階でニッケルイオンを添加 すると無機七素と難解離化合物を形成し，七素の揮散を 防ぐことにより増感効果を発揮することを報告してい る.

これらの方法はいずれも, GFAA の灰化過程において ニッケルイオンの添加が有効であることを示したもので あり, Ediger の例をみても, 湿式分解の段階における七 素の揮散は考慮されていない。

* 京都楽科大学衛生化学教室: 京都府京都市山科区御 陵中内町 5
そこで，今回通常の酸を用いる湿式分解のように，長 時間大量の酸とともに加熱されるような条件においても ニッケルイオンの添加が効果を示すかどらかを検討し, ニッケルイオン添加によって無機七素及びメチル化七素 化合物の揮散が防止され, 従って, 七素の化学形態の違 いによる定量值の差の全くみられない分解条件を設定す ることができたので報告する.

\section{2 試薬及び装置}

\section{1 試 薬}

カコジル酸 $\left[\left(\mathrm{CH}_{3}\right)_{2} \mathrm{AsO}_{2} \mathrm{H}: \mathrm{DMAA}\right.$, 和光純薬社製 $]$, 三酸化七素 (Merck 社製), 七酸水素二ナトリウム塩 (半 井化学社製)をとれぞれ蒸留水に溶かして，七素として $1000 \mathrm{ppm}$ 溶液とする. 実験に際してはこの標準溶液を 水で適宜希釈して用いた。 その他の試薬は, 特に断らな い限りすべて特級品をそのまま用いた。

\section{2 装}

原子吸光分析装置：島津 AA-640 型（パックグラウ ンド補正）及び同社製グラフォイトフォーネスフトマイ ザーGFA-2. 光源は浜松テレビ社製 $\mathrm{L}-233$ 型七素中空 陰極ランプ, 炭素炉への試料の注入には, エッペンドル フ製マイクロピペットを使用した。

ホットプレート:ヤマト科学製 $\mathrm{HK}-41$ 型. ホットプ レートは海砂を厚さ約 $5 \mathrm{~cm}$ に敷き， $190^{\circ} \mathrm{C}$ に加熱し た.

\section{3 標準操作}

\section{1 湿式分解}

試料 (1〜5) g を $50 \mathrm{ml}$ のパイレックスビーカーに入 
れ硝酸ニッケル溶液 $(100 \mathrm{mg} \mathrm{Ni2+/ml}) 5 \mathrm{ml}$ 及び硝酸 $10 \mathrm{ml}$ を加え, ホットプレート上で発ぽうが収まるまで 加熱する. 次いで硫酸 $1 \mathrm{ml}$, 過塩素酸 $(60 \%) 5 \mathrm{ml}$ を加 え引き続さ加熱する。もし液が濃縮されて炭化するよう であれば，更に硝酸 $5 \mathrm{ml}$ を加えて加熱し，分解液が黄緑 色透明になれば加熱を止める（加熱時間：約 1.5 時間). 残留液は $(2 \sim 3) \mathrm{ml}$ である. 次いでメスフラスコを用い， 蒸留水を加えて正確に $100 \mathrm{ml}$ とする.

\section{2 原子吸光測定操作}

試料溶液 $10 \mu 1$ をマイクロピペットで採取して炭素炉 に注入し, 窒素 $1.01 / \mathrm{min}$ を通気しながら炭素炉の温度 を上げて, drying $\left(15 \mathrm{~A}, 30 \mathrm{~s}, 160^{\circ} \mathrm{C}\right)$, ashing $(90 \mathrm{~A}$, $\left.25 \mathrm{~s}, 1440^{\circ} \mathrm{G}\right)$, 次いで窒素を止めて atomizing $(230 \mathrm{~A}$, $\left.7 \mathrm{~s}, 2600^{\circ} \mathrm{C}\right)$ にしてヒ素を原子化し，吸光度を測定す る. 測定はピークハイト法を採用し，スペクトル線はヒ 素 $193.7 \mathrm{~nm}$ を使用した。

\section{4 結果と考察}

\section{1 酸類共存時のニッケルイオン添加量の検討}

七素化合物として DMAA（七素として $20 \mu \mathrm{g}$ ）を用 いた場合，その揮散を防止しらるニッケルイオン量は Fig. 1 に示すよらに, 小田中らの報告と同様 GFAA の 灰化段階での添加では $10 \mathrm{mg}$ で十分であったが，硝酸， 硫酸及び過塩素酸を用いる湿式分解の場合は，このニッ ケル量では揮散を防止しえず，約 10 倍量の $100 \mathrm{mg}$ 以 上を必要とした。

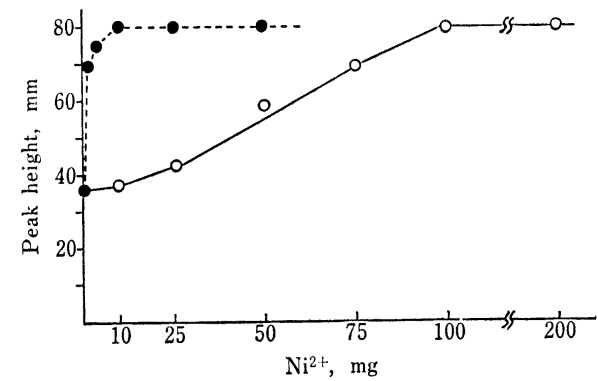

Fig. 1 Effect of $\mathrm{Ni}^{2}+$ added to $20 \mu \mathrm{g} / 100 \mathrm{ml}$ DMAA standard

- - - At the ashing in GFAA; -O- At the wet digestion with $\mathrm{HNO}_{3}, \mathrm{H}_{2} \mathrm{SO}_{4}$ and $\mathrm{HClO}_{4}$

\section{2 食品試料におけるニッケルイオンの添加量の検} 討

試料としてヒジキ $1 \mathrm{~g} ，$ コンブ $5 \mathrm{~g}$ 及びェビ $5 \mathrm{~g}$ を用
い3.1 に示す湿式分解を行い, ニッケルイオン添加量を $50 \mathrm{mg}, 100 \mathrm{mg}, 250 \mathrm{mg}, 500 \mathrm{mg}$ 及び $1000 \mathrm{mg}$ とした。 Fig. 2 に示すように $500 \mathrm{mg}$ でそれぞれのヒ素ピークは 一定となった。すなわち, 酸の共存のみでなく試料の存 在がニッケルイオンの必要量に影響を与えることが分か ったので，以後の実験ではニッケルイオン添加量を 500 mg と設定した。

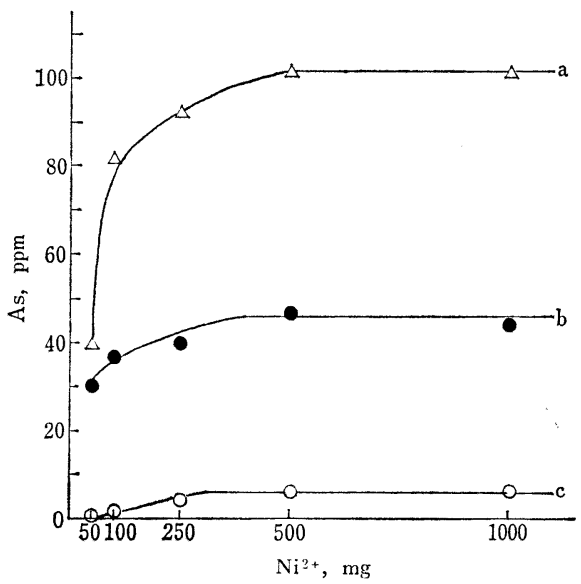

Fig. 2 Effect of added $\mathrm{Ni}^{2}+$ on wet digestion of samples

a : Hijiki (Hijikia fusiforme); $\quad$ b : Konbu (Laminaria japonica); c : Shrimp

\section{3 共存イオンの干渉}

DMAA $0.2 \mathrm{ppm}$ の標準溶液について 3.1 及び 3.2 の操作により，各種共存イオンの影響について検討した ところ, セレン(IV) は $10 \mathrm{ppm}$ 以上, 鉄(III) では 100 $\mathrm{ppm}$ 以上，又銅(II) では $500 \mathrm{ppm}$ で干渉が認められた が，その他のイオンについては 1000 ppm でも干渉が認

Table 1 Effect of diverse ions on the As peak height

\begin{tabular}{llrr}
\hline \multicolumn{1}{c}{ Ion } & \multicolumn{1}{c}{ Added as } & $\begin{array}{c}\text { Concentration } \\
(\mathrm{ppm})\end{array}$ & $\begin{array}{c}\text { Peak height } \\
(\%)\end{array}$ \\
\hline None & & & 100.0 \\
$\mathrm{Na}^{+}$ & $\mathrm{NaCl}$ & 1000 & 95.4 \\
& $\mathrm{Na}_{2} \mathrm{SO}_{4}$ & 1000 & 91.4 \\
$\mathrm{Fe}^{2+}$ & $\mathrm{FeSO}_{4}\left(\mathrm{NH}_{4}\right)_{2} \mathrm{SO}_{4} \cdot 6 \mathrm{H}_{2} \mathrm{O}$ & 1000 & 90.2 \\
$\mathrm{Fe}^{3+}$ & $\mathrm{Fe}_{2}\left(\mathrm{SO}_{4}\right)_{3} \cdot 7 \mathrm{H}_{2} \mathrm{O}$ & 500 & 68.2 \\
& & 100 & 107.4 \\
$\mathrm{Ca}^{2+}$ & $\mathrm{CaCl}_{2}$ & 1000 & 98.6 \\
$\mathrm{Cu}^{2+}$ & $\mathrm{CuSO}_{4} \cdot 5 \mathrm{H}_{2} \mathrm{O}$ & 500 & 95.8 \\
$\mathrm{Zn}^{2+}$ & $\mathrm{ZnSO}_{4} \cdot 5 \mathrm{H}_{2} \mathrm{O}$ & 1000 & 102.2 \\
$\mathrm{Mg}^{2+}$ & $\mathrm{MgSO}_{4} \cdot 7 \mathrm{H}_{2} \mathrm{O}$ & 1000 & 118.6 \\
$\mathrm{Se}^{4+}$ & $\mathrm{SeO}_{2}$ & 10 & 102.4 \\
& & 50 & 110.5 \\
& & 100 & 112.5 \\
\hline
\end{tabular}

DMAA : $0.2 \mathrm{ppm} ; \quad \mathrm{Ni}^{2+}: 5000 \mathrm{ppm}$ 
められなかった。

\section{4 他の湿式分解法との比較}

試料としてヒジキ $1 \mathrm{~g}$ を用い, 3.1 の標準操作, ケル ダール分解フラスコを用いる硫硝酸分解及びホットプレ 一ト上での硫硝酸一過塩素酸分解を行い, 硫硝酸分解及び 硫硝酸一過塩素酸分解を行った試料については，GFAA の際, 3.1 の標準操作と同濃度になるようにニッケルイ オンを添加して総七素の定量を行ったところ， Table 2 のように今回のニッケル添加湿式分解によって最も高い 值が得られ, 単に GFAA の際にニッケルイオンを添加 する方法では七素の損失は避けられず，湿式分解の段階 から添加することが必要である.

Table 2 Comparison of determination data of total As in food sample (Hijiki) by three types of wet digestion

\begin{tabular}{lr}
\hline \multicolumn{1}{c}{ Method } & \multicolumn{1}{c}{ Found (ppm) } \\
\hline $\mathrm{H}_{2} \mathrm{SO}_{4}-\mathrm{HNO}_{3}$ & $61.07 \pm 7.77(n=5)$ \\
$\mathrm{H}_{2} \mathrm{SO}_{4}-\mathrm{HNO}_{3}-\mathrm{HClO}_{4}$ & $67.85 \pm 4.51(n=5)$ \\
$\mathrm{H}_{2} \mathrm{SO}_{4}-\mathrm{HNO}_{3}-\mathrm{HClO}_{4}-\mathrm{Ni}^{2+}$ & $101.13 \pm 1.76(n=5)$ \\
\hline
\end{tabular}

\section{5 回収実験}

前項と同じヒジキ試料について DMAA の添加回収実 験を行い, Table 3 の結果を得た。すなわち回収率は 99 $\%$ 以上であり, 湿式分解時のニッケルイオン添加によっ てDMAA の損失はほぼ完全に阻止されたものと考兄ら れる。

Table 3 Recovery test

\begin{tabular}{cccc}
\hline Sample & $\begin{array}{c}\text { DMAA added } \\
(\mathrm{ppm} \text { as As) }\end{array}$ & $\begin{array}{c}\text { Found } \\
(\mathrm{ppm} \text { as As })\end{array}$ & $\begin{array}{c}\text { Recovery } \\
(\%)\end{array}$ \\
\hline Hijiki $(1 \mathrm{~g})$ & 0 & 101.1 & - \\
& 10 & 111.1 & $99.7(n=5)$ \\
& 20 & 121.0 & $99.4(n=5)$ \\
\hline
\end{tabular}

\section{6 実試料への適用}

各種食品試料中の総七素を 3.1 亿従って湿式分解し, 定量した結果を Table 4 亿示す.

$$
5 \text { 結 語 }
$$

今回, 総七素を定量するためのニッケル添加湿式分解 法を検討したが，上述のように簡易で定量性もよく, 又 ホットプレートを用い分解するため，1回に 20〜30 の 検体が処理でき，海産食品，尿，環境試料など有機七素 化合物含量の多い試料の分解法として本法は最適である
Table 4 Analysis of total As in various foods

\begin{tabular}{lcc}
\hline \multicolumn{1}{c}{ Sample } & $\begin{array}{c}\text { Fresh weight } \\
\text { (g) }\end{array}$ & $\begin{array}{c}\text { Found } \\
\text { (ppm) }\end{array}$ \\
\hline Konbu (Laminaria japonica) & 5 & 45.7 \\
Wakame (Undaria pinnatifida) & 5 & 21.0 \\
Arame (Eisenia bicyclis) & 5 & 25.7 \\
Hijiki (Hijikia fusiforme) & 1 & 101.1 \\
Dried shrimp & 5 & 6.5 \\
Hanakatsuo & 1 & 5.8 \\
Aonori & 1 & 4.5 \\
Maguro (canned) (Tunafish meat) & 5 & 2.0 \\
Akagai (canned) (Shellfish meat) & 5 & 0.6 \\
Surume (dried squid) & 5 & 0 \\
\hline
\end{tabular}

\section{と思われる。}

本研究の研究費の一部は環境庁”委託研究 “環境污染物 質の動植物体内に打ける存在形態に関する研究”の研究 費によるもので，関係各位に深謝します。

\section{交献}

1） a “衛生試験法註解”, p. 47, 48, 399(1980); b) 安井明美，堤 忠一: 分化, 26, 809(1977).

2) 小田中芳次, 俣野修身, 後藤真康 : 分化, $\mathbf{2 8}$, 517 (1979).

3) R. D. Ediger : At. Absorption Newslett., 14 (5), 127 (1975).

$$
\text { is }
$$

Wet digestion with nickel ion and graphite furnace atomic absorption spectrophotometry for the determination of total arsenic in food samples. Teruhisa Hrrayama, Yoshihiko Sakagami, Motoshi Nohara and Shozo Fukui (Kyoto Gollege of Pharmacy, 5, Nakauchi-cho, Misasagi, Yamashina-ku, Kyoto-shi, Kyoto)

Effect of nickel ion in wet digestion and graphite furnace atomic absorption (GFAA) for the measurement of total arsenic was studied. Weigh $(1 \sim 5) \mathrm{g}$ of food sample into $50 \mathrm{ml}$ Pyrex beaker. Add nickel nitrate solution ( $500 \mathrm{mg}$ as $\mathrm{Ni}$ ), $10 \mathrm{ml} \mathrm{HNO}_{3}, 1 \mathrm{ml}$ $\mathrm{H}_{2} \mathrm{SO}_{4}$, and $5 \mathrm{ml} \mathrm{HClO}_{4}$ and digest $1.5 \mathrm{~h}$ on a sand bath at $190^{\circ} \mathrm{C}$. Dilute to $100 \mathrm{ml}$ with water. A $10 \mu \mathrm{l}$-aliquot of the digested sample was injected into a graphite furnace, dried at $160^{\circ} \mathrm{G}$ for $30 \mathrm{~s}$, charred at $1440{ }^{\circ} \mathrm{G}$ for $25 \mathrm{~s}$ and atomized at $2600^{\circ} \mathrm{C}$ for $7 \mathrm{~s}$. Nitrogen $(1.01 / \mathrm{min})$ was used as the sheath gas. The absorption at $193.7 \mathrm{~nm}$ was measured. The results are as follows. (1) An addition of $10 \mathrm{mg}$ nickel as nitrate was found to give similar peak hights of GFAA for arsenic samples containing it in the form of dimethylarsinic acid (DMAA), As(III) and As(V) (each $2 \mathrm{ng}$ as As) but when the samples were prepared by wet digestion $\left(\mathrm{H}_{2} \mathrm{SO}_{4}-\mathrm{HNO}_{3}-\mathrm{HClO}_{4}\right)$, an addition of more than $100 \mathrm{mg}$ of nickel was necessary to eliminate the effect of the acids. (2) When the sample was Hijiki (Hijikia fusiforme), Konbu (Laminaria japonica) or dried shrimp, an addition of $500 \mathrm{mg}$ of nickel nitrate gave reproducible results and the interference by other ions was slight. When $10 \mathrm{ppm}$ and $20 \mathrm{ppm}$ of DMAA 
was added to $1 \mathrm{~g}$ of Hijiki sample, the recovery of DMAA was $99.7 \%$ and $99.4 \%$, if this amount of nickel was present. (3) When a Hijiki sample was digested by three types of acid mixtures, (a) sulfuric and nitric acid, (b) sulfuric, nitric and perchloric acid, and (c) sulfuric, nitric, and perchloric acid containing nickel, the last method which was proposed in this paper gave the highest value of the arsenic content.

(Received Sept. 25, 1980)

\section{Keyword phrases}

determination of total arsenic in food; wet digestion with nickel ion; graphite furnace atomic absorption; comparison of wet digestion methods.

\title{
同位体希釈-スパークイオン源質量分析法による鉄鋼中の硫黄定量*
}

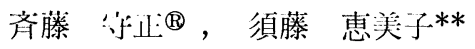 \\ (1980 年 5 月 28 日受理)
}

\begin{abstract}
$34 \mathrm{~S}$ 濃縮硫黄をスパイクとして用いる问位体希䣋ースパークイオン源質量分析法によって鉄鋼中の硫 黄定量を行った。スパイク溶液は $34 \mathrm{~S}$ 濃縮硫黄 (単体) を硝酸と塩素酸カリウムで溶解し, 調製した。 试料前処理は重量法に準じた。スパイクとともに硫黄を硫酸バリウムとして沈殿させた後, 高純度黒鉛 粉末と混合し電極を作製した。

試料溶解には硝酸と塩酸と掹素酸カリウムを用いれば硫黄の損失がないこと，使用するスパイク溶液 は経時変化があるので調製後 1 か月以内に使用する必要があることなどを明らかにした．本法による精 度は硫黄含有量が $(0.007 〜 0.029) \%$ の日本鉄鋼標準試料などに対して変動係数で $5 \%$ 以内であった。
\end{abstract}

$$
1 \text { 緒咅 }
$$

最近，鉄鋼中の硫黄は脱硫法が進むに従って含有量が 低下してきた1)．各種鉄鋼中の硫黄含有量の迅速定量法 として，発光分光分析法や，燃焼赤外線吸収法などが用 いられている．燃焼法の場合は硫酸カリウムが基準に用 いられているが，燃焼による完全抽出の問題があり，同 じ鋼種の標準試料を必要とする.

硫黄の基準分析法としては化学量論的分析法による重 量法が用いられていたが，操作が煩雑であり，特に0.01 \%以下の微量硫黄の定量に適用する場合は問題がある.

最近, 還元蒸留メチレンブルー吸光光度法がJIS に採用 された 2).しかし，硫黄の定量には微量域の定量のみな らず正確さ，及び污染の問題などがあり3)，同位体希釈質量分析法 ${ }^{4)}$ ，けい光 $\mathrm{X}$ 線分析法5) など他の方法による 比較検討がされることが望ましい.

*同位体希䣋ースパークイオン源質量分析法による金 属中の不純物の定量（第 1 報）

** 金属材料技術研究所: 東京都目黑区中目黑 2-3-12
そこで著者らは，高感度であるスパークイオン源質量 分析法と，正確さが高い同位体希釈法とを組み合わせた 方法によって検討した．同位体希釈法は重量法のように 絶対值を求める必要がないため, マトリックスの影響, 及び化学分析操作に打ける損失の誤差による問題を除く ことができる利点がある.

スパークイオン 源質量分析法を用いる同位体希釈法 は, 金属(6) 10), 岩石など地質試料 ${ }^{11)}$ の微量元素定量に応 用されているが，硫黄の定量に応用された報告はまだな い. 金属元素分析の電極試料調製の多くは電解法によっ ている.

しかし，硫黄はこの方法によって電極試料を調製する ことができないので試料前処理として重量法に準じ，す なわち硫酸バリウムを生成させて，これを高純度黒鉛粉

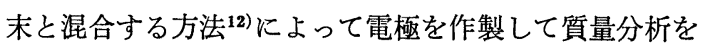
行った.

この方法によって鉄鋼中の硫黄定量の基礎条件につい て検討し良好な結果が得られたので報告する。 